\title{
CONCOMITANT PRODUCTION OF TWO PROTEASES AND ALPHA- AMYLASE BY A NOVEL STRAIN OF BACILLUS SUBTILIS IN A MICROPROCESSOR CONTROLLED BIOREACTOR
}

\author{
Hamid Mukhtar*, Ikram-ul-Haq
}

Institute of Industrial Biotechnology, Government College University, Lahore, 54000 Pakistan.

Submitted: June 30, 2010; Returned to authors for corrections: September 30, 2011; Approved: June 07, 2012.

\begin{abstract}
We describe the simultaneous production of Bacillus subtilis based proteases and alpha amylase using a computer controlled laboratory scale $7.5 \mathrm{~L}$ batch bioreactor. The present strain is the first to be reported that concomitantly produces these two industrially important enzymes. The growth and sporulation of Bacillus subtilis was monitored and maximum production of alkaline protease and alpha amylase was found to coincide with maximum sporulation. Two types of proteases were detected in the fermentation broth; a neutral and an alkaline protease most active in a $\mathrm{pH}$ range of 7.0-8.0 and 8.0-10, respectively. Maximum production of proteases was observed at an incubation temperature of $37^{\circ} \mathrm{C}$ while that of alpha amylase was observed at $40^{\circ} \mathrm{C}$. The optimum aeration and agitation levels for protease production were $0.6 \mathrm{~L} / \mathrm{L} / \mathrm{min}$ and 200rpm, respectively, and for alpha amylase were $0.6 \mathrm{~L} / \mathrm{L} / \mathrm{min}$ and $150 \mathrm{rpm}$. The kinetic parameters $\mathrm{Y}_{\mathrm{p} / \mathrm{x}}$ and qp were also found to be significant at the given fermentation conditions.
\end{abstract}

Key words: Simultaneous, sporulation, kinetics, fermentation, agitation.

\section{INTRODUCTION}

Proteases and alpha amylases are the two most important industrial enzymes, together representing more than $70 \%$ of the total worldwide enzyme market (23). Proteases catalyze the cleavage of peptide bonds and cause the total hydrolysis of proteins while alpha amylases degrade $\alpha$ 1-4 linkage of starch and other substrates in an endo fashion producing maltose and glucose $(1,22)$. Since both these enzymes are physiologically necessary for microorganisms they are widely distributed in a number of microorganisms where they are produced in large quantities by through the fermentation process.
Both fungi and bacteria are employed for the production of proteases and alpha amylases but the choice of organism mainly depends upon the application of the enzyme produced. For example, proteases to be used in the food industry are mainly produced by fungi, whereas the proteases used in leather or detergent industries are mainly produced by bacteria. Similarly, the alpha amylases produced by fungi are more stable than those from bacteria due to high thermostability and heat sensitivity (6). The most commonly used microorganisms for protease production include Bacillus spp., Steptomyces spp., Aspergillus spp., Rhizopus spp. and Penicillium spp. (2, 9, 17) and for alpha amylase production include Bacillus spp.,

*Corresponding Author. Mailing address: Institute of Industrial Biotechnology, Government College University, Lahore, 54000 Pakistan.; E-mail: hamidwaseer@yahoo.com 
Steptomyces spp., Themomyces lanuginosus, Rhizopus spp.,

Trichoderma spp., Penicillium spp. Fusarium spp. and Aspergillus spp. (7, 8, 19, 1).

Proteases and alpha amylases occupy a pivotal position with respect to their applications in industrial fields and hence have acquired great significance in present day biotechnology. Although the enzymes can be derived from several sources such as plants, animals and microorganisms, industrial demands are generally met by enzymes from microbial sources. . Proteases are widely used in brewing, baking, tenderization of meat, dairy industry, synthesis of aspartame, developing effective therapeutic agents, treatment of wounds, detergent and leather industries $(11,12,13,23)$. The alpha amylases are extensively used in many industries including paper, textile, pharmaceuticals $(8,19)$, starch liquefaction, brewing, food and sugar industries $(3,4,20)$.

Both enzymes can be produced economically and profitably on a large scale through fermentation process using a specific and potent strain. Submerged as well as solid-state fermentation techniques are used for the production of proteases and alpha amylases; however, bacteria usually give higher yields through submerged fermentation. A new trend in fermentation technology has arrived which is the simultaneous production of two or more products. In this technique, more than one product is produced by a single microorganism in a single fermentation batch under same or different conditions. Several workers have used this technique and have successfully produced more than one product simultaneously in a single batch operation $(27,10,5,25)$. This is a successful fermentation technique by which time, labor and energy can be saved and fermentation batches can be economized for maximum outputs from minimum inputs.

Keeping in mind the economics of a fermentation batch, the present work was undertaken to produce these two most important commercial enzymes simultaneously in a single strain of Bacillus subtilis using submerged fermentation technique with slight alteration of fermentation conditions.

\section{MATERIALS AND METHODS}

\section{Organism, Growth and Maintenance}

A highly productive strain of Bacillus subtilis IIB-26 was taken from the culture bank of Institute of Industrial Biotechnology, GC University, Lahore, which was originally isolated from the field soil. The culture was grown and maintained on nutrient agar medium. The bacterial slopes were incubated at $37^{\circ} \mathrm{C}$ for $48 \mathrm{~h}$ and then stored at $4^{\circ} \mathrm{C}$. However, the strain was maintained by weekly transfers onto fresh slopes.

\section{Inoculum preparation}

Inoculum of Bacillus subtilis was prepared in $500 \mathrm{~mL}$ Erlenmeyer flasks containing $100 \mathrm{~mL}$ of nutrient broth. The flasks were sterilized in an autoclave at $121^{\circ} \mathrm{C}\left(15 \mathrm{Ib} / \mathrm{in}^{2}\right.$ pressure) for $15 \mathrm{~min}$. After cooling, the medium was aseptically inoculated with bacteria from a $48 \mathrm{~h}$ old slope. The flasks after inoculation were incubated for $24 \mathrm{~h}$ on a rotary incubator shaker (Gallenkamp, UK) at $37^{\circ} \mathrm{C}$ and $200 \mathrm{rpm}$.

\section{Fermentation Experiments}

The fermentation experiments for the simultaneous production of alkaline protease and alpha amylase from Bacillus subtilis were carried out in a laboratory scale $7.5 \mathrm{~L}$ batch bioreactor (New Bruinswick Scientific, USA) with a working volume of 5.0 L. The bioreactor was equipped with monitors, which were used to measure and control foam, temperature, $\mathrm{pH}$, stirring rate and dissolved oxygen. The vessel of the bioreactor was equipped with a four-blade turbine.

Peristaltic pumps were attached to control the foam and $\mathrm{pH}$ by automatic addition of an antifoam silicon agent or an $\mathrm{acid} / \mathrm{base}$ respectively. Five liters of the fermentation medium containing $(\mathrm{g} / \mathrm{L})$ soybean meal, 20; starch, 10; glucose, 5.0; polypeptone, $10 ; \mathrm{KH}_{2} \mathrm{PO}_{4}, 1.0 ;\left(\mathrm{NH}_{4}\right)_{2} \mathrm{SO}_{4}, 1.0$ and $\mathrm{Na}_{2} \mathrm{CO}_{3}$, $5.0(\mathrm{pH} 8.0)$ was added to a fermentor vessel and sterilized in an autoclave. After cooling, the medium was inoculated with 
already-prepared $200 \mathrm{~mL}$ of the inoculum containing $3.5 \times 10^{8}$ $\mathrm{CFU} / \mathrm{mL}$. The fermentor was run for a batch operation for the said interval of time. After the fixed interval of incubation, the fermented broth was centrifuged at $3830 \mathrm{x} g$ for $10 \mathrm{~min}$ and the supernatant was assayed for protease and alpha amylase activities.

During all the experiments chemicals of analytical grade and calibrated labware were used.

\section{Analytical Methods}

Assay of Protease: The method of McDonald and Chen (16) was used for the assay of protease. Casein $(4 \mathrm{~mL}$ of $1 \%$ solution in Phosphate buffer of $\mathrm{pH} 7.0$ for the determination of neutral protease and $\mathrm{pH} 8.5$ for the determination of alkaline protease) was incubated with $1 \mathrm{~mL}$ of enzyme sample at $30^{\circ} \mathrm{C}$ for one hour. The reaction was arrested by the addition of $5 \mathrm{~mL}$ of $5 \%$ trichloroacetic acid solution. The mixture was centrifuged at $2660 \mathrm{x} \mathrm{g}$ for $10 \mathrm{~min}$ and $1 \mathrm{~mL}$ of supernatant was mixed with $5 \mathrm{~mL}$ of alkaline reagent (made by mixing 1 $\mathrm{mL}$ of $1 \% \mathrm{CuSO}_{4}, 1 \mathrm{~mL}$ of $2.7 \%$ Sodium potassium tartarate with $100 \mathrm{~mL}$ of $2 \% \mathrm{Na}_{2} \mathrm{CO}_{3}$ ). To this mixture $1 \mathrm{~mL}$ of $1 \mathrm{~N}$ $\mathrm{NaOH}$ was added to make the contents of the tube alkaline. After $10 \mathrm{~min}$., $0.5 \mathrm{~mL}$ of Folin and Ciocalteau reagent was added to the test tubes and mixed. The optical density of the solution was measured with UV/VIS spectrophotometer (CECIL, CE 7200, Cambridge, England) at $700 \mathrm{~nm}$ after 30 $\min$.

One unit of protease activity is defined as the amount of enzyme required to produce an increase of 0.1 in optical density at $700 \mathrm{~nm}$ under the defined conditions.

Assay of alpha amylase: Alpha amylase activity was estimated according to the method of Rick and Stegbauer (24). One milliliter of enzyme sample was incubated with $1 \mathrm{~mL}$ of $1 \%$ soluble starch solution (in $0.1 \mathrm{M}$ phosphate buffer $\mathrm{pH} 7.0$ ) at $40^{\circ} \mathrm{C}$ for $10 \mathrm{~min}$. The reducing sugars were measured by adding 3,5-dinitro salicylic acid reagent to the reaction mixture. The tubes were boiled for $5 \mathrm{~min}$, cooled and measured for O.D at $546 \mathrm{~nm}$ in the spectrophotometer.
One unit activity is defined as the amount of enzyme that releases one $\mu$ mole of maltose per min.

Dry cell mass: After fermentation, the fermented broth was centrifuged in preweighed glass centrifuge tubes at $3830 \mathrm{x}$ $\mathrm{g}$ for $15 \mathrm{~min}$. The supernatant was removed and the pellet was washed with water three times, then dried at $105^{\circ} \mathrm{C}$ overnight in a hot air oven. After drying, the tubes were again weighed to determine the dry cell mass (DCM) of the bacteria.

Kinetic analysis: Kinetic parameters for batch fermentation experiments were determined according to the methods described by Pirt (21) and Lawford and Rouseau (14). The following parameters of kinetics were studied:

i. Maximum specific growth rate $(\mu)_{\max }$ per $\mathrm{h}$ - The value of $(\mu)_{\max }$ was calculated from plot of $\ln x$ vs. time of fermentation, where ' $\mathrm{x}$ ' is the amount of dry cell mass.

ii. Product yield coefficient (Yp/x) U/mL/mg - The value of $\mathrm{Yp} / \mathrm{x}$ was determined by the equation:

$$
\mathrm{Y} p / \mathrm{x}=\mathrm{dp} / \mathrm{dx}
$$

Where ' $p$ ' is the amount of product $(\mathrm{U} / \mathrm{mL})$ and ' $\mathrm{x}$ ' is the amount of dry cell mass (mg).

iii. Specific product yield coefficient (qp) U/mL/h - The value of qp was determined by the equation:

$$
\mathrm{Yp} / \mathrm{x} \cdot(\mu)_{\max }
$$

\section{RESULTS AND DISCUSSION}

\section{Relationship of growth and sporulation with enzyme production}

The correlation of growth and sporulation of Bacillus subtilis with enzyme production was studied and a set of typical enzyme production curves is presented in the figure 1 along with growth and sporulation curves. Figure 1 shows that bacterial growth reached its maximum value after $24 \mathrm{~h}$ of cultivation while maximum sporulation occurred after $42 \mathrm{~h}$ of incubation. It is also clear from the results that the production rate of alpha amylase is linear up to about $36 \mathrm{~h}$ and maximum alpha amylase production coincides with maximum sporulation. In fact, the curves for alpha amylase production 
and sporulation in B. subtilis are almost identical. During the present studies, it was found that two types of proteases i,e; alkaline and neutral protease were secreted in the fermentation broth by the microorganism. It is also known from the previous studies that Bacillus subtilis produces different types of enzymes during fermentation (28). The maximum production of alkaline protease also corresponded with the point of maximum sporulation, but the maximum production of neutral protease occurred somewhat earlier at about $36 \mathrm{~h}$ of cultivation. Alkaline protease has also been named "sporulation protease" and is an absolute requirement for sporulation $(15,29)$ in $B$. subtilis hence given the name.

Under most growth conditions, Bacillus species produce extracellular protease during the post-exponential growth phase (26). Mandelstam (15) attributed this behavior to an increased need for turnover of cell proteins at the slower growth rate. Similarly the role of alpha amylase in sporulation may be energy liberation for bacteria by hydrolysis of materials present in the substrate. Overproduction of some extracellular enzymes is a reflection of the very high demands of energy and nitrogen compounds for sporulation.
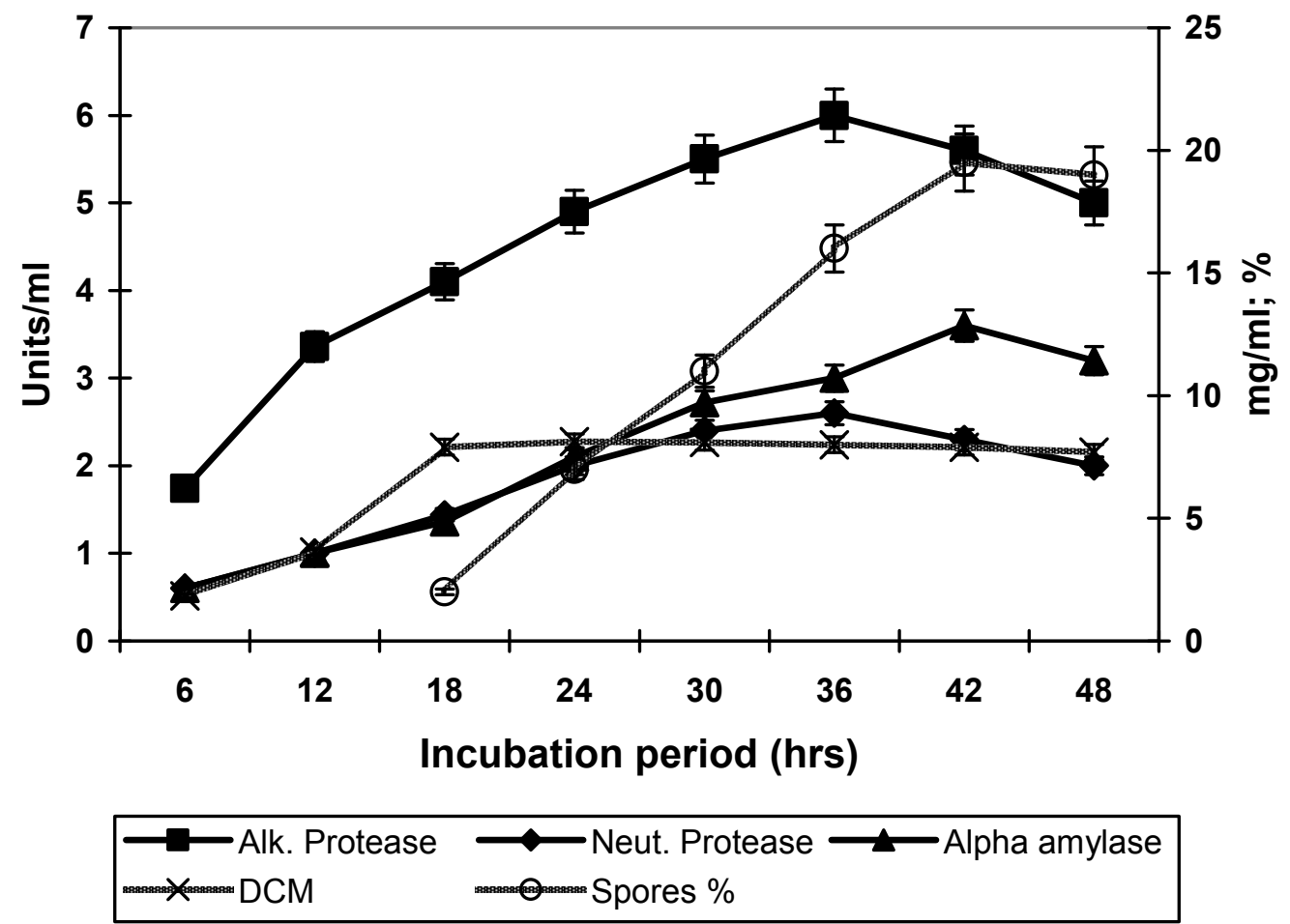

Figure 1. Relationship of growth and sporulation with the production of proteases and alpha amylase by Bacillus subtilis. Inc. temperature: $35^{\circ} \mathrm{C}$; Agitation: 200rpm; Aeration: $0.6 \mathrm{~L} / \mathrm{L} / \mathrm{min}$. Values are the mean of three replicates.

\section{Effect of incubation temperature on enzyme production}

The effect of incubation temperature $\left(30-50^{\circ} \mathrm{C}\right)$ on enzyme production, cell growth and sporulation was also studied and the results are presented in Figure 2. The cell mass was increased as the temperature was increased from $25^{\circ} \mathrm{C}$, reached maximum $(8.5 \mathrm{mg} / \mathrm{mL})$ at $40^{\circ} \mathrm{C}$, and then started decreasing which shows the inhibiting effect of higher temperature on the growth of the organism. Sporulation shows a progressive increase from 25 to $35^{\circ} \mathrm{C}(3-17 \%)$ and between 35 and $50^{\circ} \mathrm{C}$, it was fairly constant $(17-19 \%)$, in which 
temperature range, the yield of alpha amylase was also found to be maximum. However, production of proteases appeared to be maximum at a cultivation temperature of $37^{\circ} \mathrm{C}$.

For alpha amylase production, it appears that a temperature of $40^{\circ} \mathrm{C}$ is optimal whilst for protease the optimum was around $37^{\circ} \mathrm{C}$. There was very sharp maximum for proteolytic activity near $37^{\circ} \mathrm{C}$, whilst the maximum for alpha amylase was observed at $40^{\circ} \mathrm{C}$ and was much less sharp. The kinetic parameters also revealed the same results as depicted in the experiments. The product yield coefficient $\left(\mathrm{Y}_{\mathrm{p} / \mathrm{x}}\right)$ and specific product yield coefficient (qp) for protease production were maximum at $37^{\circ} \mathrm{C}$ showing the optimum temperature for protease production while in case of alpha amylase production the kinetic parameters showed maximum values at an incubation temperature of $40^{\circ} \mathrm{C}$ (Table 1$)$.
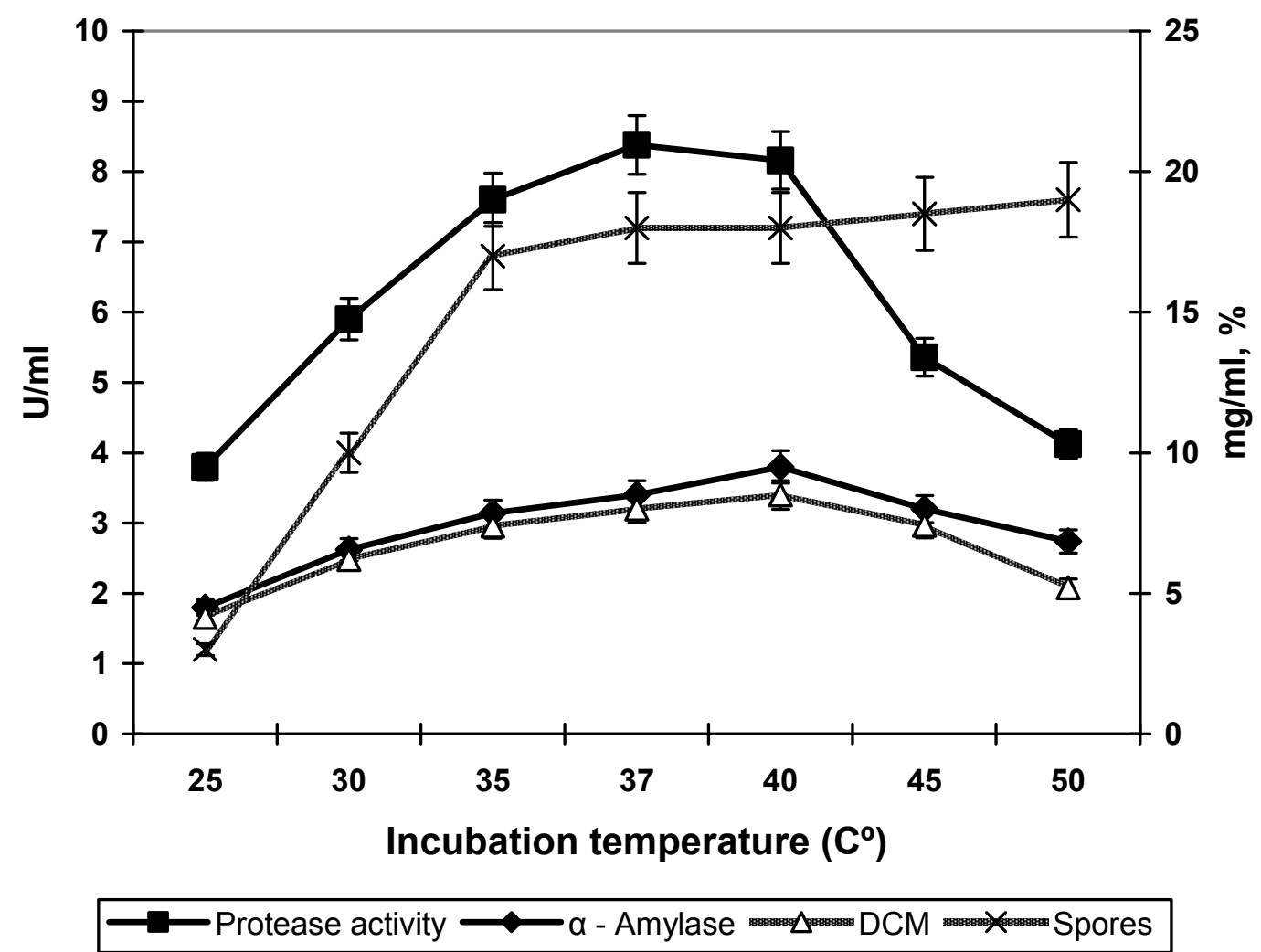

Figure 2. Effect of incubation temperature on the production of protease and alpha amylase by Bacillus subtilis. Inc. period: 42hrs; Agitation: 200rpm; Aeration: $0.6 \mathrm{~L} / \mathrm{L} / \mathrm{min}$. Values are the mean of three replicates.

Table 1. Product yield coefficient $\left(\mathrm{Y}_{\mathrm{p} / \mathrm{x}}\right)$ and specific rate of product formation ( $\mathrm{qp}$ ) of Bacillus subtilis at different incubation temperatures

\begin{tabular}{|c|c|c|c|c|}
\hline $\begin{array}{l}\text { Incubation } \\
\text { temperature }\left(C^{0}\right)\end{array}$ & $\begin{array}{l}Y_{p / x} \text { for protease } \\
(\mathrm{U} / \mathrm{mL} / \mathrm{mg})\end{array}$ & $\begin{array}{l}\text { qp for protease } \\
(\mathrm{U} / \mathrm{mL} / \mathrm{h})\end{array}$ & $\begin{array}{l}Y_{p / x} \text { for alpha amylase } \\
(\mathrm{U} / \mathrm{mL} / \mathrm{mg})\end{array}$ & $\begin{array}{l}\text { qp for alpha amylase } \\
(\mathrm{U} / \mathrm{mL} / \mathrm{h})\end{array}$ \\
\hline 25 & 0.917 & 0.121 & 0.434 & 0.057 \\
\hline 30 & 0.951 & 0.126 & 0.422 & 0.056 \\
\hline 35 & 1.02 & 0.135 & 0.437 & 0.058 \\
\hline 37 & 1.047 & 0.139 & 0.425 & 0.056 \\
\hline 40 & 0.96 & 0.127 & 0.45 & 0.059 \\
\hline 45 & 0.722 & 0.096 & 0.431 & 0.057 \\
\hline 50 & 0.686 & 0.091 & 0.430 & 0.057 \\
\hline
\end{tabular}




\section{Effect of aeration and agitation on enzyme production}

In the experiments concerned with variation in aeration $(0.2-$ $1.0 \mathrm{~L} / \mathrm{L} / \mathrm{min}$ ), the maximum cell mass was found at an aeration rate of $0.6 \mathrm{~L} / \mathrm{L} / \mathrm{min}$, in conjunction with a sporulation rate of $18.5 \%$ (Figure 3). These properties of growth and sporulation corresponded to the maximum production of both the enzymes tested.

In the agitation experiments, variable stirring speeds ranging from 100 - 300 rpm were evaluated (Fig. 4). Stirring speeds lower than $200 \mathrm{rpm}$ were not sufficient to keep the solids in the medium in homogeneous suspension; they also failed to break the clumps of cells. On the other hand, a speed higher than $250 \mathrm{rpm}$ was found to cause excessive foaming thus necessitating the automatic addition of such large quantities of antifoam agent (silicon oil) that enzyme yields were impaired. In addition, the lower speed (150 $\mathrm{rpm}$ ) was found to be slightly better for alpha amylase production, but for proteases the higher speed $(200 \mathrm{rpm})$ produced significantly better results (18).

The values of $Y_{p / x}$ and $q p$ obtained after kinetic analysis of results revealed that the best aeration and agitation rates for protease production were $0.6 \mathrm{~L} / \mathrm{L} / \mathrm{min}$ and $250 \mathrm{rpm}$, respectively while for alpha amylase production the same aeration rate but a different agitation rate i,e; $150 \mathrm{rpm}$ was found significant (Tables $2,3)$.

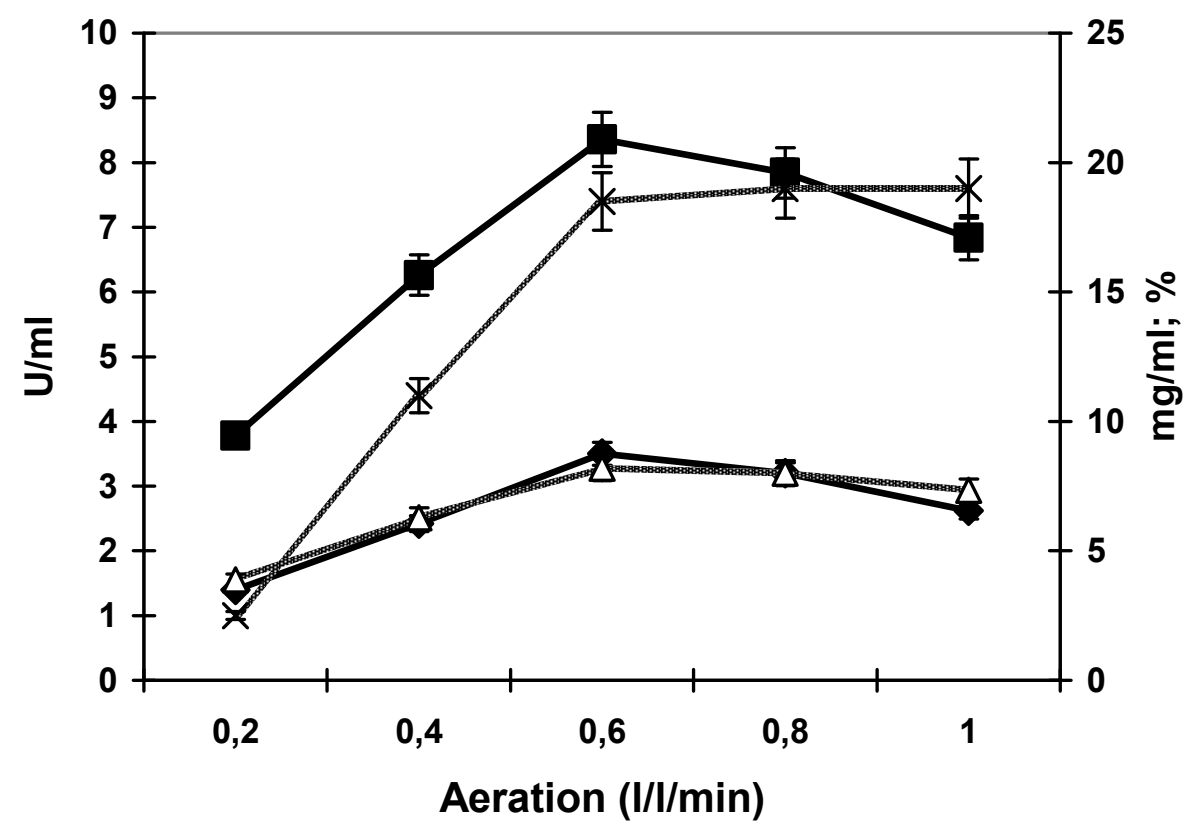

$\longrightarrow \alpha-$ Amylase $\sim$ Protease $\sim \sim$ DCM

Figure 3. Effect of aeration on the production of proteases and alpha amylase by Bacillus subtilis. Inc. temperature: $35 \mathrm{C}^{\circ}$; Agitation: 200rpm; Inc. period: $42 \mathrm{hrs}$. Values are the mean of three replicates.

Table 2. Product yield coefficient $\left(\mathrm{Y}_{\mathrm{p} / \mathrm{x}}\right)$ and specific rate of product formation (qp) of Bacillus subtilis at different aeration levels

\begin{tabular}{lllll}
\hline $\begin{array}{l}\text { Aeration } \\
(\mathbf{L} / \mathbf{L} / \mathbf{m i n})\end{array}$ & $\begin{array}{l}\mathbf{Y}_{\mathbf{p} / \mathbf{x}} \text { for protease } \\
(\mathbf{U} / \mathbf{m L} / \mathbf{m g})\end{array}$ & $\begin{array}{l}\mathbf{q p} \text { for protease } \\
(\mathbf{U} / \mathbf{m L} \mathbf{h})\end{array}$ & $\begin{array}{l}\mathbf{Y}_{\mathbf{p} / \mathbf{x}} \text { for } \text { alpha amylase } \\
(\mathbf{U} / \mathbf{m L} / \mathbf{m g})\end{array}$ & $\begin{array}{l}\mathbf{q p} \text { for alpha amylase } \\
(\mathbf{U} / \mathbf{m} \mathbf{L} / \mathbf{h})\end{array}$ \\
\hline 0.2 & 0.97 & 0.129 & 0.36 & 0.047 \\
0.4 & 0.99 & 0.131 & 0.38 & 0.050 \\
0.6 & 1.02 & 0.135 & 0.42 & 0.055 \\
0.8 & 0.98 & 0.130 & 0.40 & 0.053 \\
1.0 & 0.93 & 0.123 & 0.35 & 0.046 \\
\hline
\end{tabular}




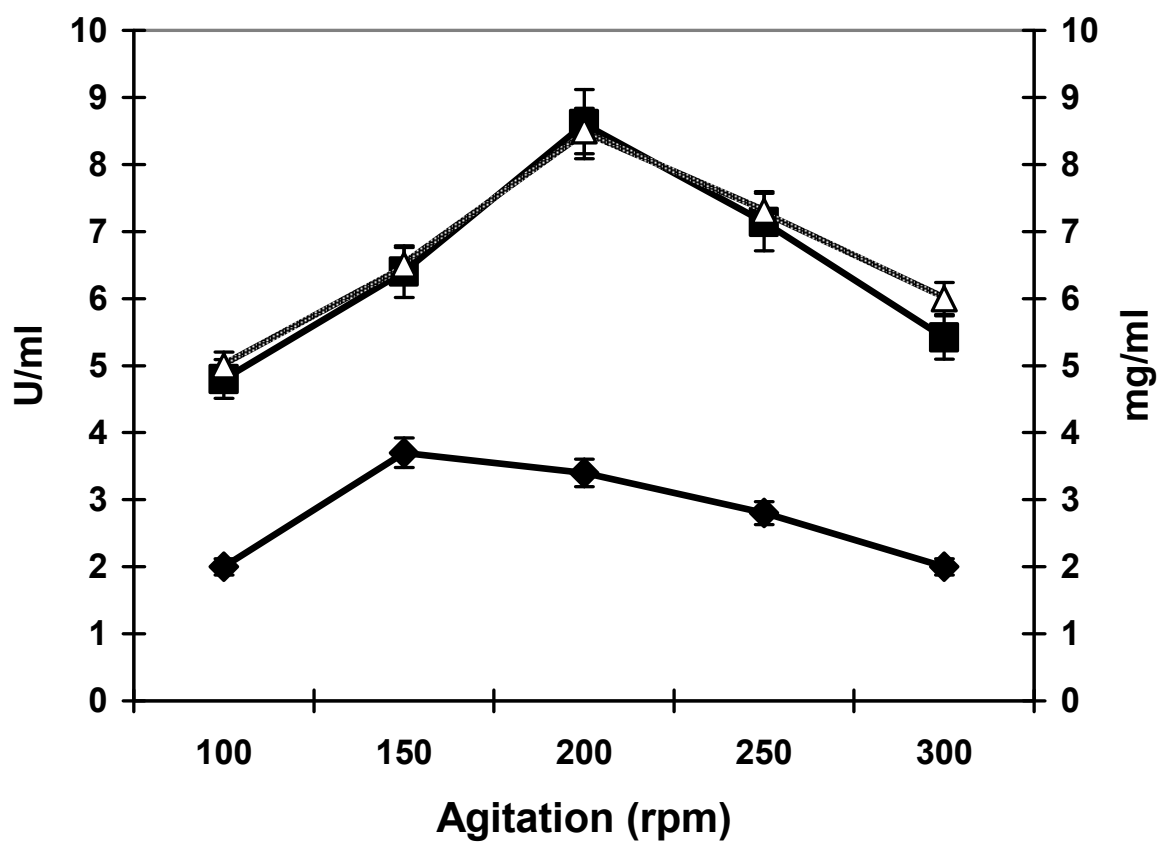

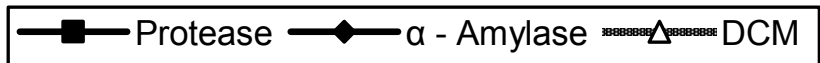

Figure 4. Effect of agitation on the production of proteases and alpha amylase by Bacillus subtilis. Inc. temperature: $35 \mathrm{C}^{\circ}$; Inc. period: $42 \mathrm{hrs}$; Aeration; $0.6 \mathrm{~L} / \mathrm{L} / \mathrm{min}$. Values are the mean of three replicates.

Table 3. Product yield coefficient $\left(\mathrm{Y}_{\mathrm{p} / \mathrm{x}}\right)$ and specific rate of product formation (qp) of Bacillus subtilis at different agitation rates

\begin{tabular}{|c|c|c|c|c|}
\hline Agitation (rpm) & $\begin{array}{l}Y_{\mathrm{p} / \mathrm{x}} \text { for protease } \\
(\mathrm{U} / \mathrm{mL} / \mathbf{m g})\end{array}$ & $\begin{array}{l}\text { qp for protease } \\
\text { (U/mL/h) }\end{array}$ & $\begin{array}{l}Y_{p / x} \text { for alpha amylase } \\
(\mathrm{U} / \mathrm{mL} / \mathrm{mg})\end{array}$ & $\begin{array}{l}\text { qp for alpha amylase } \\
(\mathrm{U} / \mathrm{mL} / \mathrm{h})\end{array}$ \\
\hline 100 & 0.96 & 0.127 & 0.4 & 0.053 \\
\hline 150 & 0.98 & 0.130 & 0.56 & 0.074 \\
\hline 200 & 1.01 & 0.134 & 0.4 & 0.053 \\
\hline 250 & 0.97 & 0.129 & 0.38 & 0.050 \\
\hline 300 & 0.90 & 0.119 & 0.33 & 0.043 \\
\hline
\end{tabular}

\section{CONCLUSION}

We conclude that the present strain of Bacillus subtilis can simultaneously produce alpha amylase and protease in high titers. The production was substantially enhanced by optimization of culture conditions. The strain can be proved very useful commercially for the production of proteases and amylase in a single batch operation.

\section{ACKNOWLEDGEMENTS}

We are thankful to Dr. Adrian Briggs, Department of
Genetics, Harvard Medical School, USA for reviewing the manuscript.

\section{REFERENCES}

1. Abdullah, R.; Ashraf, H.; Haq, I. (2003). Optimization and kinetic analysis of carbon sources on the production of alpha amylase by Saccharomyces cerevisiae. J. Food Technol. 1(4), 187-190.

2. Adinarayana, K.; Ellaiah, P. (2002). Response surface optimization of the critical medium components for the production of alkaline protease by a newly isolated Bacillus sp. J. Pharm. Pharmaceut. Sci. 5(3), 272278.

3. Batlle, N.; Carbonell, J.V.; Sendra, J.M.; (2000). Determination of 
depolymerization kinetics of amylose, amylopectin and soluble starch by Aspergillus oryzae ' $\alpha$-amylase' using a fluorimetric 2-p-toluidine naphthalene-6-sulfonate /flow injection analysis system. Biotechnol. Bioeng. 70(5), $552-554$.

4. Carlsen, M.; Nielsen, J.; Villadsen, J. (1996). Growth and alpha amylase production by Aspergillus oryzae during continuous cultivations. J. Biotechnol. 45(1), 81-93.

5. Chuanbin, L.; Yan, L.; Wei, L.; Zhiyou, W.; Dongmei, W.; Shulin, C. (2005). Nisin and Lactic Acid Simultaneous Production from Cheese Industry Byproducts: Optimization of Fermentation Conditions Through Statistically Based Experimental Designs, Department of Biological Systems Engineering, Washington State University, Pullman, WA, 99164-6120.

6. Duochuan, L.; Yijun, Y.; Youliang, P.; Chongyao, S.; Peijin, Z.; Yicum, H. (1997). Purification and properties of a thermostable alpha amylase from the thermophilic fungus Thermomyces lanuginosus. Acta. Microbiol. SIN. 37(2), 107-114.

7. Fogarty, W.M.; Dooyle, E.M.; Kelly, C.T. (1999). Comparison of the action pattern 2 high maltose forming alpha amylase on linear maltooligosaccharides. Enzyme Microbiol. Technol. 25(3-5), 330-335.

8. Haq, I.; Abdullah, R.; Ashraf, H.; Shah, A.H. (2002). Isolation and screening of fungi for the biosynthesis of alpha amylase. J. Biotechnol. $1(2-4), 61-66$

9. Haq, I.; Mukhtar, H. (2004). Biosynthesis of protease by Rhizopus oligosporous $\mathrm{IHS}_{13}$ by solid-state fermentation in a low cost medium. $J$. Basic Microbiol., 44(4), 280-287.

10. Hari, K.S.; Chowdary, G.V. (2000). Optimization of simultaneous saccharification and fermentation for the production of ethanol from lignocellulosic biomass. J. Agric Food Chem. 48(5), 1971-6.

11. Inhs, D.A.; Schmidt, W.; Richter, F.R. June 1999. Proteolytic enzyme cleaner. US Pat. 5961366.

12. Kalisz, M.H. (1988). Microbial Proteinases. Adv. Biochem. Eng. Biotechnol. 36, 17-55.

13. Kumar, C.G.; Tagaki, H.; (1999). Microbial alkaline proteases: from a bio-industrial viewpoint. Biotechnol. Adv. 17, 561-594.

14. Lawford, H.G; Roseau, J.D. (1993). Mannose fermentation by ethanologenic recombinants of E. coli and kinetical aspects. Biotechnol. Lett. 15, 615-620.

15. Mandelstam, J. (1958). Turnover of protein in growing and nongrowing population of Escherichia coli. Biochem J. 69, 110-119.

16. McDonald, C.E.; Chen, L.L. (1965). Lowry modification of the Folin reagent for determination of proteinase activity. Annals Biochem. 10, 175.

17. Mohamed, A.; Abdel, N.; Ismail, A.M.S.; Ahmed, S.A.; Ahmed F.; Fattah, A.; (1998). Production and Immobilization of alkaline protease from Bacillus Mycoides. Bioresource Technol. 64, 205-210.

18. Mukhtar, H.; Haq, I. (2008). Production of alkaline protease by Bacillus subtilis and its application as a depilating agent in leather processing. Pak. J. Bot. 40(4), 1673-1679.

19. Nascimento, W.C.A.; Martins, M.L.L. (2004). Production and properties of an extracellular protease from thermophilic Bacillus sp. Braz. J. Microbiol., 35(1-2), 91-96.

20. Nigam, P.; Singh, D. (1995). Enzymes and microbial system involved in starch processing enzyme. Microb. Technol. 17, 770-778.

21. Ohdan, K.; Kuriki, T.; Takata, H.; Okada, S. (2000). Introduction of raw starch-binding domains in to Bacillus subtilis alpha amylase by fusion with the starch-binding domain of Bacillus cyclomaltodextrin glucanotransferase. Appl. Environ. Microbiol. 66(7), 3058-3064.

22. Pirt, S.J. (1975). Principles of cell and microbe cultivation. Blackwells Scientific, USA.

23. Ramachandran, S.; Patel, A.K.; Nampoothiri, K.M.; Chandran, S.; Szakacs, G.; Sccol, C.R.; Pandey, A. (2004). Alpha amylase from a fungal culture grown on oil cakes and its properties. Braz. Arch. Biol. Technol. 47(2), 309-317.

24. Rao, M.B.; Tanksale, A.M.; Ghatge, M.S.; Deshpande, V.V. (1998). Molecular and biotechnological aspects of microbial proteases. Microbiol. Mol. Biol. Rev. 62, 597-635.

25. Rick, W.; Stegbauer, H.P. (1974). Alpha amylase of reducing groups. In: Bergmeyer, H. V. (Ed) Methods of Enzymatic Analysis, Vol. 2, Academic Press, New York., p 885-890.

26. Sangeetha, R; Geetha, A; Arulpandi, I. (2010) Concomitant production of protease and lipase by Bacillus licheniformis VSG1: production, purification and characterization. Braz. J. Microbiol., 41

27. Schaeffer, P. (1969). Sporulation and production of antibiotics, exoenzymes and exotoxins. Bacteriol. Rev., 33, 48-71.

28. Toropova, E.G.; Maksimov, V.N.; Tkhaker, V.; Egorov, N.S. (1984). Selection of the medium for the simultaneous synthesis of an antibiotic, protease and pigment by a Nocardia fructiferi culture. Nauchnye Doki. Vyss. Shkoly Biol. Nauki., 10, 96-101.

29. Yoneda, Y.; Maruo, B. (1975). Mutation of Bacillus subtilis causing hyperproduction of alpha amylase and protease and its synergistic effect. J Bacteriol., 124(1), 48-54. 